\title{
PENGARUH SELF-ACTUALIZATION DAN GAYA HIDUP HANGOUT TERHADAP KEPUTUSAN PEMBELIAN DI KEDAI KOPI KEKINIAN PADA GENERASI MILENIAL SURABAYA
}

\author{
Diyah Widiyanti ${ }^{1 *}$, Harti Harti \\ ${ }^{1,2}$ Universitas Negeri Surabaya, Jl. Lidah Wetan, Kec. Lakarsantri, Surabaya 60213 \\ Email:Diyahwidiyanti16080324075@mhs.unesa.ac.id; harti@unesa.ac.id \\ *Penulis korespondensi
}

\begin{abstract}
Abstrak: Penelitian Tujuan penelitian ini adalah untuk mengetahui pengaruh self-actualization dan gaya hidup hangout terhadap keputusan pembelian di kedai kopi kekinian pada generasi milenial Surabaya. Jenis penelitian yang dipakai adalah kuantitatif melalui pendekatan asosiatif. Teknik pengambilan sampel yakni non probability sampling dengan menggunakan 210 responden yaitu konsumen yang sudah melakukan pembelian di kedai kopi kekinian minimal 1 kali. Teknik pengumpulan data memakai kuesioner pada googleform dengan skala likert 1-4 dengan jumlah 21 item pernyataan. Setelah data terkumpul kemudian melakukan teknik analisis data. Teknik analisis data memakai regresi linier berganda melalui bantuan SPSS 23.0. Hasil dari penelitian ini menunjukkan bahwasanya variabel Self-Actualization (X1) mempunyai pengaruh signifikan terhadap keputusan pembelian. Gaya hidup hangout (X2) mempunyai pengaruh signifikan terhadap keputusan pembelian. SelfActualization dan gaya hidup hangout mempunyai pengaruh secara simultan terhadap keputusan pembelian di kedai kopi kekinian pada generasi milenial Surabaya.
\end{abstract}

Kata kunci: Self-Actualization; gaya hidup hangout; keputusan pembelian.

\begin{abstract}
The purpose of this study was to determine the effect of self-actualization and the hangout lifestyle on purchasing decisions in contemporary coffee shops in Surabaya's millennial generation. The type of research used is quantitative through an associative approach. The sampling technique is non-probability sampling using 210 respondents, namely consumers who have made purchases at contemporary coffee shops at least once. The data collection technique used a questionnaire on google form with a Likert scale of 1-4 with a total of 21 statement items. After the data is collected then perform data analysis techniques. The data analysis technique used multiple linear regression with the help of SPSS 23.0. The results of this study indicate that the Self-Actualization (X1) variable has a significant effect on purchasing decisions. The hangout lifestyle (X2) has a significant effect on purchasing decisions. Self-Actualization and the hangout lifestyle have a simultaneous influence on purchasing decisions at contemporary coffee shops in Surabaya's millennial generation.
\end{abstract}

Keywords: Self-Actualization; hangout lifestyle; purchase decisions.

\section{PENDAHULUAN}

Kota Surabaya sebagai ibu kota Provinsi Jawa Timur dan juga menjadi kota metropolitan yang memiliki potensi besar menjadi ladang uang untuk perusahaan serta pecinta usaha kuliner guna melakukan pengembangan bisnis seperti cafe, kedai kopi yang bermacam-macam tipenya menjadi tren di kota Surabaya. Didukung oleh adanya beberapa Universitas yang berada di Surabaya menjadikan peluang bisnis besar dengan sasaran kaum milenial yang salah satunya adalah mahasiswa yang berasal dari berbagai daerah. Beberapa golongan menamai anak-anak muda masa kini menjadi generasi milenial. Generasi tersebut lahir sesudah zaman generasi $\mathrm{X}$, ataupun lebih tepat di tahun 1980 hingga tahun 2000-an. Di Indonesia, terdapat kira-kira 80 juta orang berusia 17 hingga 37 tahun. Jumlah yang tergolong banyak dan signifikan, mengingat populasi generasi milenial telah mencakup 30 persen dari keseluruhan penduduk yang ada di Indonesia (https://kompasiana.com).
Generasi milenial lahir ketika bermunculan cangggihnya media sosial di Indonesia, sehingga sangat wajar apabila generasi milenial lebih modern dan mengikuti pergerakan zaman. Terdapat kecenderungan milenial yang lebih suka nongkrong atau yang biasa disebut hangout dan mendengarkan musik bersama teman-teman. Dilansir dari Bisnis.com (2019), Asosiasi Pengusaha Kafe dan Restoran Indonesia mengutarakan bahwa gaya hidup masyarakat dan milenial kota menjadi salah satu faktor pertumbuhan kafe berbasis kopi meningkat sebesar $16 \%$ hingga tahun 2019.

Hasil Survei Sosial Ekonomi Nasional (Susenas) yang dilakukan Badan Pusat Statistik (BPS) tahun 2018, sebesar 63,82 juta jiwa masuk kategori pemuda. Perhitungan tersebut ialah seperempat dari total penduduk Indonesia. Berdasarkan hasil perhitungan jumlah pemuda, trend minuman kopi para pemuda berpotensi besar dalam peningkatan jumlah kebutuhan kopi di Indonesia. Pernyataan tersebut didukung data International Coffee Organization (ICO) yang 
membuktikan trend peningkatan konsumsi kopi di Indonesia. ICO merilis data pertumbuhan jumlah konsumsi kopi di Indonesia, yaitu sebesar 8\% tahun 2015, lebih besar dari pada pertumbuhan dunia sebesar $6 \%$. Sebanding ICO, data perhitungan konsumsi kopi yang dirilis pusat data dan sistem informasi pertanian kementrian pertanian tahun 2018 membuktikan ada tingkatan konsumsi kopi nasional selama 4 tahun terakhir. Rata-rata konsumsi kopi nasional tumbuh mencapai 2,49\%. (https://suara.com).

Kedai kopi ialah sarana yang dipakai oleh masyarakat Indonesia khususnya generasi milenial untuk bercanda tawa, bertukar pikiran, dan atau berdiskusi bersama ataupun sarana menghilangkan lelah setelah beraktivitas. Kedai kopi pada umumnya didesain biasa yang mana menjual aneka makanan dan minuman terutama kopi. Menurut salah satu pemerhati gaya hidup dan makanan, peningkatan tren konsumsi minuman berkafein dimulai sejak 6 tahun silam yang dibuktikan dengan laporan dunia yang membuktikan peralihan dari bar ke kedai kopi, di Indonesia sendiri menikmati kopi dianggap sebagai pecinta produk lokal karena salah satu kekayaan sumberdaya di Indonesia (Cahya, 2017). Rutinitas atau kunjungan ke kedai kopi ini telah ada di negara kita sejak dahulu dan mengalami perubahan budaya yang mana akibat adanya globalisasi dan gaya modern. Perubahan kedai kopi masa dulu dengan masa sekarang atau yang biasa disebut kedai kopi kekinian dapat diamati dari gedung, konsep tatanan yang modern serta hidangan yang beragam.

Dilihat dari sudut pembeli, kedai kopi dulu menjadi wadah berkumpulnya orang dewasa, namun sekarang sebaliknya menjadi tempat bergabung atau hangout remaja masa sekarang atau generasi milenial. Kedai kopi kekinian atau dijuluki Coffee Shop secara umum menawarkan tempat yang rapi dan menarik dengan properti/alat yang bersih dan rapi serta menomor satukan pembelinya. Dengan berbagai hal yang ditawarkan seperti tata ruang modern, internet gratis, dan layanan yang baik. Sekarang, ngopi atau hangout di Coffe shop menjadi kebiasaan dan kebutuhan para remaja.

Bisnis kopi yang berkembang saai ini adalah bisnis yang cukup menggiurkan, karena kopi bukan lagi sebagai penghilang rasa ngantuk, tapi sudah menjadi gaya baru bagi peminatnya. Kedai kopi pada masa sekarang bisa ditemui dengan sangat mudah. Satu titik di Surabaya yang panjangnya tak lebih dari 5 kilometer secara mudah ditemukan empat sampai lima kedai kopi kekinian

Persaingan yang sengit bisa dijumpai dari usaha sejenis yang beradaptasi di Kota Surabaya. Dengan sajian hidangan dan harga yang hampir sama membuat setiap kedai kopi kekinian bersaing dalam keunikan atau khas yang menarik minat pembeli. Berdasarkan data dari beberapa kedai kopi kekinian yang ada di Surabaya tersebut, peneliti melakukan penelitian pada 4 kedai kopi kekinian yang hampir satu tahun berdiri dan ramai dikunjungi oleh banyak generasi milenial di Surabaya yaitu kedai kopi Janji jiwa, Kopi Kenangan, Rocketman Coffee, dan Jokopi.

Kotler dan Amstrong (2012:192) mengartikan gaya hidup ialah cara hidup manusia di dunia yang diekspresikan dalam kegiatan, minat dan pendapatnya. Gaya hidup mencerminkan keseluruhan diri dalam melakukan interaksi dengan lingkungannya. Gaya hidup mencerminkan cara seseorang dalam menunjukkan aksi dan melakukan interaksi di dunia. Aktivitas hangout merupakan salah satu gaya hidup yang populer dan sangat digemari para remaja khusunya di kota besar seperti di Surabaya ini. Saat ini remaja dan dewasa muda memilih menghabiskan waktu senggangnya untuk berkumpul dan hangout bersama teman-teman untuk sekedar ngobrol atau mengerjakan tugas sembari minum kopi. Pada masa modern, hangout memiliki beragam hal yang diperhatikan. Generasi milenial menjadi sangat teliti tentang tempat di mana mereka akan hangout. Tempat yang akan dituju lebih baiknya tempat yang memiliki unsur menarik sesuai dengan keinginan setiap orang khusunya orang milenial. Oleh karena itu kedai kopi yang sudah ada harus memiliki konsep yang sesuai tujuannya agar pembeli dapat menikmati suasana yang membuat tenang dan nyaman sehingga pembeli merasa ingin berlama-lama di dalam kedai kopi. Dengan kebiasaan hangout generasi milenial dapat menjadi peluang yang besar bagi pengusaha dan orang lain untuk berbisnis.

Coffe Shop menjadi wadah berkumpul populer dan bergengsi di kalangannya. Selain itu, sisi populer kedai kopi juga berpengaruh pada pikiran orang bahwa tempat nongkrong sama dengan kedai kopi. Bagi remaja milenial, berkunjung ke kedai kopi ialah cara populer dimana tidak hanya membeli kopi namun menikmati prestise yang mengikutinya akibat budaya ke kedai kopi tersebut sehingga tidak sulit ditemui remaja sekarang yang pergi kesana hanya untuk memperhitungkan status sosial yang dianggap tinggi. Kebiasaan ini berkaitan erat dengan kebutuhan aktualisasi diri (self-actualization).

Abraham Maslow dalam (Jess Feist dkk: 2017) aktualisasi diri atau self-actualization merupakan langkah menjadi diri sendiri dan penggunaan potensi secara penuh, seiring berjalannya waktu aktualisasi diri akan berkembang dan tekanan aktualisasi diri akan beralih dari segi fisiologis menuju psikologis. Pada fase remaja aktualisasi diri dapat dilakukan dengan mengikuti beragam tren atau keunikan yang sedang ada seperti musik, fashion, kecanggihan alat, 
kebudayaan dan lain-lain. Penelitian ini mengkhususkan aktualisasi diri dan gaya hidup hangout pada generasi milenial di kedai kopi kekinian, bentuk aktualisasi diri di kedai kopi kekinian antara lain mengupdate status, unggah foto bersama melalui media sosial. Tindakan mengunggah status ketika di kedai kopi kekinian saat ini tak jarang dilakukan oleh remaja sekarang maka tanpa disadari menjadi perilaku yang umum, namun jika dikaji mendalam ialah ungkapan diri dimana seseorang ingin diperhatikan dan dikagumi orang lain. Selain meng-update status melalui di media sosial remaja juga membagi foto bersama. Selain mengunggah foto diri, juga banyak remaja membagi foto produk yang dibeli dengan tampilan sebuah brand dari kedai kopi yang didatangi. Perilaku membagi foto barang dengan menunjukkan brand kedai kopi terkenal tak disadari saat ini, dengan maksud memberitahukan atau membagi informasi kepada khalayak bahwa mereka sedang melakukan tren yang ada.

Keputusan pembelian ialah pemikiran seseorang dengan melakukan evaluasi banyak pilihan dan menjatuhkan satu pilihan dari beragam pilihan yang sejenis. Kotler \& Amstrong (2012), keputusan pembelian ialah salah satu tahap dalam proses pengambilan keputusan pembeli di mana pembeli benar-benar membeli. Sedangkan Prasetijo dan Ihalauw (2005: 226) mengartikan "keputusan sebagai suatu pemilihan tindakan dari dua atau lebih pilihan alternatif". Dari beberapa definisi di atas maka bisa dibuat kesimpulan bahwasanya, keputusan pembelian ialah keputusan pembelian pelanggan dengan bermacam-macam tahap pilihan alternatif ketika melakukan pemuasan kebutuhan.

Penulis berusaha memahami perilaku remaja milenial dalam menunjukkan aktualisasi yang mana saat ini kedai kopi menjadi pilihan untuk mewujudkannya. Hal ini membuat unsur yang menarik karena sebagai orang yang masih dalam proses menempuh pendidikan, tugas utama mereka ialah belajar dan menggali ilmu, tapi sesuatu yang berkembang di sekitar akan menjadi kebiasaan. Hal tersebut mempengaruhi orang untuk mengikuti gaya dan tidak sulit ditemui mereka pergi ke kedai kopi hingga larut malam.

Tujuan penelitian ini adalah untuk mengetahui pengaruh antara Self-Actualization dan gaya hidup hangout terhadap keputusan pembelian di kedai kopi kekinian. Penelitian ini terfokus pada konsumen kedai kopi kekinian di Surabaya. Berdasarkan latar belakang di atas penulis tertarik untuk meneliti kedai kopi kekinian dengan judul "Pengaruh Self-Actualization dan Gaya Hidup Hangout Terhadap Keputusan Pembelian di Kedai Kopi Kekinian Pada Generasi Milenial Surabaya"

\section{LANDASAN TEORI}

\section{Perilaku Konsumen}

Menurut Engel, Blackwell dan Miniard dalam (Schiffman, 2004:5) yaitu pemahaman terhadap perilaku konsumen mencakup pemahaman terhadap tindakan yang langsung dan dilakukan konsumen dalam mendapatkan, mengkonsumsi dan menghabiskan produk dan jasa, termasuk proses keputusan yang mendahului dan mengikuti tindakan tersebut, sebagaimana dinyatakan dalam berikut ini:

"consumer behaviour as those activities directly involved in obtaining, consuming, and disposing of products and service, including the decision processes that precede and follow these actions".

Hal yang hampir sama diungkapkan oleh Schiffman dan Kanuk (2004) bahwa perilaku konsumen merupakan studi yang mengkaji bagaimana individu membuat keputusan membelanjakan sumberdaya yang tersedia dan dimiliki (waktu, uang, dan usaha) untuk mendapatkan barang atau jasa yang nantinya akan dikonsumsi. Dalam studi ini dikaji tentang apa yang mereka beli, mengapa mereka membeli, dimana mereka membeli dan bagaimana (berapa sering membeli) dan bagaimana mereka menggunakannya.

Sedangkan Mowen:2002 menjelaskan bahwa perilaku konsumen mencakup proses pengambilan keputusan dan kegiatan yang dilakukan konsumen secara fisik dalam pengevaluasian, perolehan penggunaan atau mendapatkan barang dan jasa. Jadi di dalam menganalisis perilaku konsumen tidak hanya menyangkut faktor-faktor yang mempengaruhi pengambilan keputusan kegiatan saat pembelian, akan tetapi juga meliputi proses pengambilan keputusan yang menyertai pembelian.

\section{Self-Actualization}

Salendra (2014:7) mengemukakan bahwa aktualisasi diri merupakan keinginan individu memperdalam potensi yang ada pada dirinya untuk berkembang serta mencapai hasil maksimal untuk mendapatkan kepuasan pada dirinya, keinginan, untuk menjadi dirinya sendiri dan juga untuk menyempurnakan dirinya, serta keinginan untuk mencapai puncak prestasi dengan kemampuan dan potensi yang dimiliki. Hersinta dan Soepomo (dalam Sunarti, 2018:2) berpendapat bahwa aktualisasi diri merupakan sebuah keadaan dimana seorang manusia telah merasa menjadi dirinya sendiri, mengerjakan sesuatu yang disukainya dengan hati yang gembira dan ikhlas.

Poduska (dalam Peni, 2019:292) menyatakan bahwa aktualisasi diri merupakan hasrat individu 
untuk menyempurnakan pribadinya melalui pengungkapan potensi yang dimilikinya. Yulianti (2018: 292) menambahkan bahwa aktualisasi diri merupakan kebutuhan individu yang paling tinggi dan timbul ketika kebutuhan sebelumnya terpuaskan.

Jadi dapat disimpulkan bahwa aktualisasi diri merupakan kebutuhan tertinggi dari seorang individu, kebutuhan aktualisasi diri ini dapat dicapai ketika kebutuhan-kebutuhan lainnya yang lebih rendah telah terpenuhi seperti kebutuhan fisiologis, rasa aman, kasih sayang dan penghargaan.

\section{Gaya Hidup Hangout}

Menurut Mangkunegara (2009:80) Gaya hidup secara luas didefiniskan sebagai cara hidup yang di identifikasikan oleh bagaimana seseorang menghabiskan waktu mereka (aktivitas), apa yang mereka anggap penting dalam lingkungannya (ketertarikan), dan apa yang mereka pikirkan tentang diri mereka sendiri dan juga dunia di sekitarnya (pendapat).

Gaya hidup suatu masyarakat akan berbeda dengan masyarakat lainnya. Bahkan dari masa ke masa gaya hidup suatu individu dan kelompok masyarakat tertentu akan bergerak dinamis. Namun demikian, gaya hidup tidak cepat berubah sehingga pada kurun waktu tertentu gaya hidup relatif permanen.

Menurut Mowen (2002:252) gaya hidup adalah "A mode of living that is identified by how people spend their time (activities), what they consider important in their environment (interest), and what they think of themselvesand the world around them (opinions)".

Hangout dalam (Ujang:2011) merupakan salah satu aktivitas yang dilakukan manusia untuk merilekskan pikiran mereka.

\section{Kerangka Konseptual}

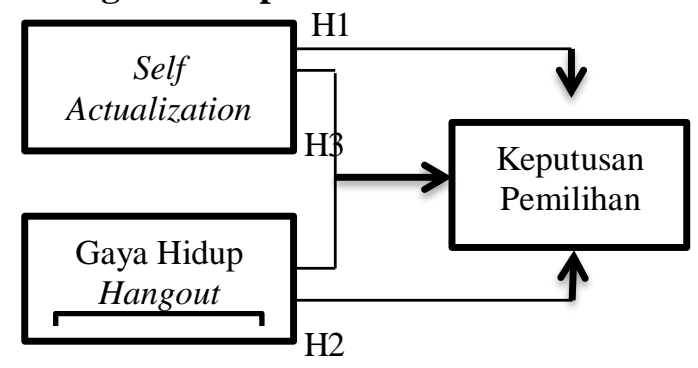

Gambar 1. Kerangka Konseptual

\section{Hipotesa}

\section{Hubungan Self-Actualization terhadap keputusan pembelian}

Suwartini (2016:2) aktualisasi diri menjadi keadaan seorang dimana merasa menjadi diri sendiri, melakukan hal yang disuka dengan gembira dan ikhlas. Poduska (dalam Subawa, (2020) mengartikan bahwa aktualisasi diri ialah hasrat menyempurnakan pribadi melalui ungkapan potensi yang dimiliki. Subawa (2020) aktualisasi diri ialah kebutuhan seseorang tertinggi dan muncul saat kebutuhan sebelumnya telah puas didapatkan. Penelitian Fitrayanti (2015) menunjukkan bahwa terdapat pengaruh yang signifikan secara parsial antara motivasi, kepribadian dan konsep diri, dan gaya hidup.

Indikator pengukuran self-actualization pada penelitian ini adalah kebutuhan pertumbuhan, kebutuhan pencapaian potensi seseorang, penemuan diri dan kebutuhan dorongan.

Penelitian yang dilakukan oleh Salendra (2014), hasil penelitian yaitu aktualisasi diri ialah kebutuhan tertinggi seseorang, wujud aktualisasi diri remaja bermacam-macam, ada yang meng-update foto di banyak media sosial mereka berakibat diketahui banyak orang. Penelitian yang dilakukan Sholeh (2017) aktualisasi diri berpengaruh positif terhadap keputusan pembelian. Faktor yang mempengaruhi keputusan pembelian antara lain motivasi, persepsi, pembelajaran, serta kepercayaan dan sikap.

$\mathrm{H}_{1}$ : Terdapat pengaruh Self-Actualization terhadap keputusan pembelian di kedai kopi kekinian pada generasi milenial Surabaya.

\section{Hubungan gaya hidup hangout terhadap keputus- an pembelian}

Gaya hidup seseorang dapat diamati melalui kegiatan, minat, dan pendapat. Gaya hidup akan menunjukkan suatu tingkah laku yang mengarah pada tujuan pemenuhan kebutuhan yang dirasakan. Jadi kegiatan yang dilakukan seseorang dipengaruhi oleh dorongan dalam diri, kekuatan pendorong inilah yang dinamakan gaya hidup. Berdasarkan Yulianti, dkk (2018) hasil dari penelitian ini menyatakan bahwa gaya hidup berhubungan kuat menuju sangat kuat dengan keputusan pembelian serta berpengaruh yang positif dan searah. Penelitian yang dilakukan oleh Yulianti, dkk (2018) hasil menyatakan bahwa variabel gaya hidup memiliki pengaruh yang signifikan terhadap variabel keputusan pembelian. Menurut Schiffman (2012:75) gaya hidup mengacu pada cara konsumsi yang menunjukkan pilihan seseorang mulai penghabisan waktu dan uang. Gaya hidup yang mengalir melalui secangkir kopi menjadikan pilihan gaya hidup yang bisa didapatkan, diisi ulang, atau bahkan ditingkatkan (Malhotra, 2010: 6-7). Penelitian Sholeh (2017) yaitu studi menunjukkan bahwa ada hubungan yang signifikan antara gaya hidup dengan kepuasan hidup. 
Hal ini menunjukkan bahwa gaya hidup menjadi faktor yang mempengaruhi perilaku konsumen dalam pembelian. Pola hidup orang yang diwujudkan melalui kegiatan, minat, dan pendapat yang lebih dari kelas sosial dan pribadi seseorang. Gaya hidup hangout pada penelitian ini diberi batasan yakni aktifitas, minat dan opini.

$\mathrm{H}_{2}$ : Terdapat pengaruh gaya hidup hangout terhadap keputusan pembelian di kedai kopi kekinian pada generasi milenial Surabaya.

\section{Hubungan Self-Actualization dan gaya hidup hangout terhadap keputusan pembelian}

Yulianti (2018:7) aktualisasi diri ialah kemauan seseorang dalam menggali potensi dirinya dengan tujuan berkembang serta mendapat hasil maksimal guna meraih kepuasan pada dirinya, keinginan untuk menjadi dirinya sendiri dan juga untuk menyempurnakan dirinya, serta keinginan untuk mencapai puncak kemampuan dan potensi yang dimiliki. Menurut Schiffman (2012:75) gaya hidup mengacu pada pola konsumsi yang menunjukkan pilihan seseorang dari penghabisan waktu dan uang yang dilakukan.

Perilaku konsumen adalah studi tentang unit pembelian (buying unit) dan proses pertukaran yang melibatkan perolehan, konsumsi dan pembuangan barang, jasa, pengalaman, serta ide-ide (Mowen dan Minor, 2002:6). Menurut Schiffman and Kanuk (2008:485), Keputusan adalah seleksi terhadap dua pilihan atau lebih. Dengan kata lain, pilihan alternatif harus tersedia bagi seseorang ketika mengambil keputusan. Ujang (2015:286), pengambilan keputusan konsumen meliputi semua proses yang dilakukan oleh konsumen dalam mengenali suatu masalah, mencari solusi, mengevaluasi alternatif, dan memutuskan untuk memilih diantara beberapa pilihan. Hal ini menunjukkan bahwa Self-Actualization dan gaya hidup menjadi faktor yang mempengaruhi perilaku konsumen dalam pembelian.

$\mathrm{H}_{3}$ : Terdapat pengaruh Self-Actualization dan gaya hidup hangout terhadap keputusan pembelian di kedai kopi kekinian pada generasi milenial Surabaya.

\section{METODE PENELITIAN}

\section{Populasi}

Populasi dimaksud ialah pembeli yang berkunjung di 4 kedai kopi kekinian yaitu kedai kopi Janji Jiwa, Kopi Kenangan, Rocketman Coffee, Jokopi. Dalam penelitian ini populasi yang diteliti sebanyak 210 responden. Dengan karakteristik responden adalah 1) Konsumen yang sudah melakukan pembelian di kedai kopi kekinian minimal 1 kali. 2) Responden berusia antara 15 sampai 40 tahun. Perihal tersebut disebabkan karena umur 15-40 tahun adalah golongan usia remaja lanjut yang milenial.

\section{Sampel}

Teknik pengambilan sampel yang digunakan yaitu teknik non probability sampling. Teknik pengumpulan data memakai kuesioner pada googleform dengan skala likert 1-4 dengan jumlah 21 item pernyataan. Peneliti mengambil sampel bejumlah 210 responden.

\section{Definisi Operasional}

1. Self-Actualization $\left(\mathrm{X}_{1}\right)$

a. Kebutuhan Pertumbuhan (Growth Need) $\left(\mathrm{X}_{1.1}\right)$ Kebutuhan pertumbuhan adalah kebutuhan untuk mengetahui dan memahami sesuatu, untuk tumbuh dan berkembang dengan dihargai orang lain.

b. Produk Tiruan Kebutuhan Pencapaian potensi seseorang (Achieving One's Potential) $\left(\mathrm{X}_{1.2}\right)$ Yaitu kebutuhan seseorang untuk mengembangkan kemampuan yang ada dalam dirinya secara maksimal.

c. Kebutuhan dorongan $\left(\mathrm{X}_{1.3}\right)$

Dorongan dalam diri individu untuk mempertahankan keberadaan dirinya sesuai dengan potensi yang dimilikinya.

2. Gaya Hidup Hangout $\left(\mathrm{X}_{2}\right.$

a. Aktivitas (Activity) $\left(\mathrm{X}_{2.1}\right)$

Menggunakan pengukuran gaya hidup melalui indikator hobi, hiburan, dan belanja.

b. Minat (Interest) $\left(\mathrm{X}_{2.2}\right)$

Menggunakan pengukuran gaya hidup melalui indikator fashion, makanan, dan media

c. Opini (Opinion) $\left(\mathrm{X}_{2.3}\right)$

Menggunakan pengukuran gaya hidup melalui indikator opini diri sendiri, pendidikan, dan budaya.

3. Keputusan pembelian (Y)

a. Perhatian (Attention) $\left(\mathrm{Y}_{1.1}\right)$

Perhatian calon konsumen terhadap produk yang ditawarkan oleh produsen.

b. Ketertarikan (Interest) $\left(\mathrm{Y}_{1.2}\right)$

Ketertarikan calon konsumen terhadap produk yang ditawarkan oleh produsen.

c. Keinginan (Desire) $\left(\mathrm{Y}_{1.3}\right)$

Keinginan calon konsumen untuk memiliki produk yang ditawarkan oleh produsen.

d. Tindakan (Action) $\left(\mathrm{Y}_{1.4}\right)$

Cara konsumen melakukan pembelian terhadap produk yang ditawarkan. 


\section{Uji Asumsi Klasik}

1. Uji Normalitas

Uji ini digunakan menguji populasi data, variabel dependen, variabel indepeden terdistribusi normal atau tidak. Seperti telah dketahui bahwa uji t dan uji $\mathrm{F}$ pada suatu penelitian mengasumsikan bahwa nilai residual mengikuti distribusi normal (Malhotra, 2016:154). Uji klomogrov-Smirnov merupakan metode yang digunakan untuk uji normalitas. Jika signifikan hasil uji klomogrov-Smirnov dengan taraf signifikan $>0,05$, maka data tersebut terdistribusi nomal dan jika sebaliknya maka terdistribusi tidak normal.

2. Uji Multikolinearitas

Uji Multikolinearitas memiliki tujuan untuk menunjukkan hubungan kuat antar 2 variabel bebas atau lebih dalam model regresi berganda (Malhotra, 2016:154). Hal ini dapat dilihat pada nilai Tolerance dan Variance Inflating Factor (VIF) dengan menggunakan dasar pengambilan keputusan:

a) Tolerance $>0,10$ tidak terjadi multikolinieritas

b) Tolerance $<0,10$ terjadi multikolinieritas, atau sama dengan

a) $\mathrm{VIF}<10,00$ tidak terjadi multikolinieritas

b) VIF $>10,00$ terjadi multikolinieritas

3. Uji Heterokesdastisitas

Uji heteroskedastisitas memliki tujuan menguji ada tidaknya ketidaksamaan variance dari residual satu pengamatan ke pengamatan lain dalam model regresi, karena pada regresi yang baik adalah yang homokesdastisitas atau tidak terjadi heteroskedastisitas (malhotra, 2016:134). Uji heterokesdastisitas menggunakan uji glejser dengan sig > 0,05 menyatakan tidak ada gejala heteroskesdastisitas.

\section{Teknik Analisis Data}

1. Analisis Regresi Linear Berganda

Analisis regresi diartikan ketergantungan variabel terikat dengan variabel bebas, yang memiliki kegunaan memprediksi rata-rata populasi atau nilai rata-rata variabel dependen berdasarkan nilai variabel independen yang diketahui (Malhotra, 2016:93). Analisis menspekulasi yang dapat melibatkan lebih dari satu variabel disebut analisis regresi berganda. Adapun persamaan regresi dalam penelitian ini sebagai berikut:

$$
\mathrm{Y}=a+b \mathrm{X} 1+b \mathrm{X} 2+e
$$

Keterangan:

$Y=$ Keputusan pembelian

$a=$ Konstanta Persamaan Regresi

$b=$ Koefisien regersi masing-masing variabel bebas
$X_{1}=$ Self Actualization

$X_{2}=$ Gaya Hidup Hangout

$e=$ Faktor lain diluar penelitian

2. Analisis Koefisien Determinasi

Koefisien Determinasi $\left(\mathrm{R}^{2}\right)$ dasarnya guna menghitung besar kemampuan model saat menjelaskan variasi variabel keputusan pembelian. Nilai koefisien determinasi yaitu antara nol dan satu.

3. Ujit

Uji parsial (Uji T) berguna menguji hipotesis apabila peneliti ingin mengetahui hubungan variabel self actualization dan gaya hidup hangout dengan variabel keputusan pembelian. Uji t untuk menguji kebenaran pernyataan atau dugaan yang dihipotesiskan peneliti (Sholeh, 2017:194). Dalam penelitian ini menggunakan SPSS 23. untuk menguji uji $\mathrm{t}$ yang signifikannya $<0,05$ maka variabel self actualization dan gaya hidup hangout memiliki pengaruh terhadap variabel keputusan pembelian.

4. Uji F

Uji simultan untuk mengetahui hubungan variabel bebas bersamaan terhadap variabel terikat. Menurut Ghozali (2013:98). Uji F dinamakan uji signifikasi secara menyeluruh terhadap garis regresi yang diobservasi. Untuk menguji uji $\mathrm{F}$ digunakan dengan cara melihat nilai $\mathrm{F}$ hitung dengan nilai $\mathrm{F}$ table. Jika nilai $\mathrm{F}$ hitung $>\mathrm{F}$ table maka $\mathrm{H}_{\mathrm{o}}$ ditolak dan $\mathrm{H}_{\mathrm{a}}$ diterima.

\section{HASIL DAN PEMBAHASAN}

Berdasarkan hasil penelitian yang dilaksanakan melalui penyebaran sebuah angket yang berjumlah 210 responden. Penyebaran angket yang sudah dilengkapi oleh responden ditemukan hasil karakteristik responden pada tabel 1 .

Tabel 1. Karakteristik Responden

\begin{tabular}{lcc}
\hline Karakteristik & Jumlah & Presentase \\
\hline Usia & & \\
$15-20$ & 36 & $17,1 \%$ \\
$21-30$ & 166 & $79,1 \%$ \\
$31-40$ & 8 & $3,8 \%$ \\
Jenis kelamin & & \\
Perempuan & 132 & $62,9 \%$ \\
Laki-laki & 78 & $37,1 \%$ \\
Pekerjaan & & \\
Pelajar & 7 & $3,3 \%$ \\
Mahasiswa & 155 & $73,8 \%$ \\
Wiraswasta & 11 & $5,2 \%$ \\
PNS/Swasta & 22 & $10,5 \%$ \\
Lainnya & 15 & $7,2 \%$ \\
\hline Sr: Dia &
\end{tabular}

Sumber: Data diolah peneliti, 2020 
Diketahui karakteristik responden berdasarkan usia yang membeli di kedai kopi kekinian Surabaya dominan pada usia 21-30 tahun dengan presentase $79,1 \%$. Artinya yang paling banyak melakukan pembelian di kopi kekinian Surabaya adalah responden dengan rentan usia 21-30 tahun. Dikarenakan umur 2130 adalah generasi milenial yang suka nongkrong dan menikmati kopi dikedai kekinian. Konsumen yang melakukan pembelian dominan perempuan dengan presentase $62,9 \%$. Artinya responden yang berkunjung dan melakukan pembelian di kopi kekinian Surabaya didominasi oleh konsumen perempuan karena sebagian besar perempuan suka menghabiskan waktu untuk ngobrol, bersantai dikedai kopi kekinian. Dan didominasi oleh mahasiswa dengan presentase $73,8 \%$. Karena mahasiswa membeli kopi dikedai kekinian untuk mengerjakan tugas, kegiatan kuliah dan nongkrong bersama teman-temannya.

\section{Uji Asumsi Klasik}

Untuk mengolah data yang diperoleh peneliti melakukan uji asumsi klasik untuk memenuhi asumsi parametrik sebelum melakukan uji analisis regresi linear berganda menggunakan SPSS 23.0

Hasil uji asumsi klasik terdiri dari empat uji dan diolah menggunakan SPSS 23.0 for windows, berikut penjabaran masing-masing uji:

\section{Uji Normalitas}

Berdasarkan pada SPSS 23.0 dapat diketahui bahwa hasil uji normalitas pada penelitian SelfActualization dan gaya hidup hangout terhadap keputusan pembelian, nilai signifikansi uji normalitas dari unstandardized residual adalah 0,200. Artinya nilai residual tersebut lebih besar dari 0,05 sehingga nilai residual dinyatakan terdistribusi normal dan data dapat dikatakan normal.

2. Uji Multikolinieritas

Berdasarkan hasil uji SPSS 23.0 dapat diketahui variabel self actualization (X1) dan gaya hidup hangout (X2) terhadap keputusan pembelian (Y) masing-masing memiliki nilai tolerance sebanyak 0,507 terbukti semuanya memiliki nilai $>0,1$. Sedangkan nilai VIF X1 dan X2 sebesar 1,971 lebih dari nilai $<10$ hal ini menyatakan bahwa tidak adanya gejala multikolinieritas.

3. Uji Heteroskedastisitas

Berdasarkan Uji SPSS 23.0 dapat diketahui bahwa titik-titik menyebar acak dan tidak membentuk pola serta pada uji Glesjer nilai p X1 sebanyak 0,415 dan X2 sebanyak 0,381 yang semuanya $>0,05$ sehingga dalam penelitian ini tidak terjadi gejala heteroskedastisitas.

4. Uji Linier

Uji linier menjelaskan bahwa hasil yang diperoleh nilai Deviation from Linearity yang memiliki nilai
Sig 0,195 yang lebih besar dari 0,05. Maka dapat disimpulkan bahwa adanya hubungan linier signifikan antara variabel self actualization (X1) dan gaya hidup hangout (X2) terhadap keputusan pembelian (Y)

\section{Analisis Regresi Linear Berganda}

Tabel 2. Regresi Linear Berganda

\begin{tabular}{lccc}
\hline \multirow{2}{*}{ Model } & \multicolumn{2}{c}{$\begin{array}{c}\text { Unstandardized } \\
\text { Coefficients }\end{array}$} & $\begin{array}{c}\text { Standardized } \\
\text { Coefficients } \\
\text { Beta }\end{array}$ \\
\cline { 2 - 3 } & B & Std. Error & \\
\hline Constant & 6.992 & 1.032 & \\
X2 & .514 & .082 & .415 \\
X1 & .388 & .068 & .381 \\
\hline
\end{tabular}

Sumber: Diolah peneliti, 2020

Berdasarkan hasil diatas, maka didapatkan rumus persamaan regresi berganda sebagai berikut:

$$
\mathrm{Y}=6,992+0,514 \mathrm{X} 1+0,388 \mathrm{X} 2+\varepsilon
$$

Berdasarkan persamaan regresi linier tersebut, maka bisa didapatkan beberapa pernyataan berikut ini:

Konstanta 6,992 bernilai positif (+) dapat diartikan apabila variabel bebas yaitu self actualization dan gaya hidup hangout $=0$ (tidak ada perubahan) maka nilai variabel keputas pembelian sebesar 6,992. Artinya, apabila kedua variabel bebas yaitu self actualization dan gaya hidup hangout tidak mengalami perubahan maka akan tetap terjadi keputusan pembelian dikarenakan pengaruh dari variabel diluar penelitian.

Nilai koefisien regresi variabel self actualization (X1) sebesar 0,514 bernilai positif (+) yang berarti jika self actualization naik satu satuan, maka keputusan pembelian akan meningkat sebesar $51,4 \%$. Sedangkan nilai signifikansi sebesar 0,000 menunjukkan bahwa self actualization bernilai signifikan yang artinya besar sampel mewakili kebenaran dari jumlah populasi.

Nilai koefisien regresi variabel gaya hidup hangout (X2) sebesar 0,388 bernilai positif (+) yang berarti jika gaya hidup hangout naik satu satuan, maka keputusan pembelian akan meningkat sebesar 38,8\%. Sedangkan nilai signifikansi sebesar 0,000 menunjukkan bahwa gaya hidup hangout bernilai signifikan yang artinya besar sampel mewakili kebenaran dari jumlah populasi.

\section{Analisis Koefisien Determinasi $\left(\mathbf{R}^{2}\right)$}

Tabel 3. Koefisien Determinasi

\begin{tabular}{ccc}
\hline Model & R Square & Adjusted R squeres \\
\hline 1 & .539 & .535
\end{tabular}

Sumber: Diolah peneliti, 2020 
Nilai determinasi $\mathrm{R}^{2}$ dipakai untuk melihat sejauh mana kemampuan model regresi dalam menerangkan self actualization dan gaya hidup hangout terhadap variabel keputusan pembelian. Koefisien determinasi nilai R Square sebesar 0,539 atau 53,9\%. Kontribusi variabel bebas self actualization dan gaya hidup hangout terhadap keputusan pembelian bernilai 53,9\% sedangkan terdapat sisa sebesar $46,1 \%$ dijelaskan oleh variabel lainnya yang tidak diteliti. Sehingga variabel bebas yaitu self actualization dan gaya hidup hangout secara bersamaan berpengaruh terhadap keputusan pembelian di Kedai kopi kekinian Surabaya

\section{Uji t}

Tabel 4. Uji t

\begin{tabular}{ccr}
\multicolumn{3}{c}{ Coefficients } \\
\hline Model & $\mathbf{t}$ & \multicolumn{1}{c}{ Sig. } \\
\hline (Constant) & 6,776 &, 000 \\
x1 & 6.265 &, 000 \\
x2 & 5.749 &, 000 \\
\hline
\end{tabular}

a. Dependent Variable: $y$

Sumber: Data diolah peneliti, 2020

Tabel berikut menyatakan bahwa diperoleh hasil sebagai berikut:

a. Hipotesis pertama (H1)

hasil uji $\mathrm{t}$ pada variabel self actualization (X1) menunjukkan nilai signifikansi 0,000 tidak lebih dari 0,05 yang bermakna signifikan dan nilai $t$ hitungnya lebih banyak dibandingkan $t$ tabelnya $(6,265>1,987)$. Maka kesimpulan yang diambil yaitu self actualization (X1) berpengaruh terhadap keputusan pembelian $(\mathrm{Y})$, sehingga hipotesis pertama dapat diterima.

b. Hipotesis kedua $(\mathrm{H} 2)$

Hasil uji t pada variabel gaya hidup hangout (X2) menunjukkan nilai signifikansi sebesar 0,000 tidak lebih dari 0,05 yang bermakna signifikan dan nilai $\mathrm{t}$ hitungnya lebih banyak dibandingkan $\mathrm{t}$ tabelnya (5,749>1,987). Maka kesimpulan yang diambil yaitu gaya hidup hangout (X2) berpengaruh terhadap keputusan pembelian (Y), sehingga hipotesis kedua dapat diterima.

\section{Uji F}

Tabel 5. Uji F

\begin{tabular}{lccc}
\hline \multicolumn{1}{c}{ Model } & Sum of Squares & F & Sig. \\
\hline 1 Regression & 2732,341 & 121,091 & $.000^{\mathrm{b}}$ \\
Residual & 2335,416 & & \\
Total & 5067,757 & & \\
Sumber: Data diolah oleh peneliti, 2020 & &
\end{tabular}

Sumber: Data diolah oleh peneliti, 2020

Berdasarkan tabel dapat dilihat bahwa $\mathrm{F}$ hitung 121,091 lebih besar dari F tabel 21,011. Tingkat signifikan 0,000 lebih kecil dari 0,05 sehingga dapat dikatakan bahwa $\mathrm{H}_{3}$ diterima, yaitu variabel SelfActualization $\left(\mathrm{X}_{1}\right)$ dan gaya hidup hangout $\left(\mathrm{X}_{2}\right)$ berpengaruh simultan terhadap keputusan pembelian. Hal ini membuktikan bahwa Self-Actualization dan gaya hidup hangout menjadi faktor yang berpengaruh terhadap perilaku konsumen dalam pembelian.

\section{Pembahasan}

\section{Pengaruh Self-Actualization $\left(\mathrm{X}_{1}\right)$, terhadap ke- putusan pembelia (Y) di kedai kopi kekinian pada generasi milenial Surabaya.}

Berdasarkan hasil uji t pada variabel self actualization (X1) menunjukkan nilai signifikansi 0,000 tidak lebih dari 0,05 yang bermakna signifikan dan nilai $t$ hitungnya lebih banyak dibandingkan $\mathrm{t}$ tabelnya $(6,265>1,987)$. Maka kesimpulan yang diambil yaitu self actualization (X1) berpengaruh terhadap keputusan pembelian $(\mathrm{Y})$, sehingga hipotesis pertama dapat diterima.

Poduska (dalam Syafitri, 2014:292) menyimpulkan aktualisasi diri ialah hasrat manusia guna penyempurna diri melalui pengungkapan potensi yang dimiliki. Self-actualization terhadap keputusan pembelian pada kedai kopi kekinian di Surabaya dapat dilihat dari 1) kebutuhan pertumbuhan yaitu merasa memiliki obsesi yang tinggi dan memiliki reputasi yang baik ketika berada di kedai kopi kekinian. 2) Kebutuhan pencapaian potensi seseorang yaitu dengan berada dikedai kopi kekinian merasa lebih percaya diri dan menunjukkan kemampuan yang dimiliki. 3) Kebutuhan pemenuhan diri yaitu berada di kedai kopi kekinian merasa terjamin dan memberikan kenyamanan.

Dari hasil penyebaran angket melalui googlefrom bahwa variabel Self-actualization pada pernyataan konsumen mampu membeli kopi kekinian mendapatkan presentase tertinggi yaitu $35,7 \%$. Artinya berdasarkan data yang diperoleh melalui penyebaran googleform di Surabaya bahwa konsumen mampu membeli kopi dikedai kopi kekinian yaitu Janji Jjiwa, Kopi Kenangan, Rocketman Coffee, Jokopi, untuk memenuhi Selft- actualization. Menurut Mangkunegara, (2009) perilaku konsumen merupakan suatu tindakan-tindakan yang dilakukan oleh individu, kelompok atau organisasi yang berhubungan dengan proses pengambilan keputusan dalam mendapatkan, dan menggunakan barang-barang atau jasa ekonomi yang dapat dipengaruhi oleh lingkungan.

Konsumen membeli kopi dengan harga berapapun untuk memenuhi Selft- actualization dan kepuasan pada dirinya. Sehingga banyak dijumpai konsumen yang membeli kopi tetapi bukan pecinta kopi tetapi mereka membeli karena faktor lain misalnya kopi 
yang lagi trend, pengaruh dari teman, tempat nongkrong dengan view instragammable untuk diupload ke media sosial. Syafitri (2014) menyatakan aktualisasi diri ialah kebutuhan orang tertinggi dan terjadi saat kebutuhan sebelumnya telah puas didapat. Hasil dari penelitian ini sesuai dengan Salendra (2014), menyatakan bahwa aktualisasi diri berpengaruh positif terhadap keputusan pembelian.

Berdasarkan hasil penelitian tersebut dan penelitian pendukung lainnya, maka dalam penelitian ini dapat diketahui bahwa H1 diterima yaitu Self-Actualization berpengaruh terhadap keputusan pembelian di kedai kopi kekinian.

\section{Pengaruh gaya hidup hangout $\left(\mathrm{X}_{2}\right)$ terhadap keputusan pembelian (Y) di kedai kopi kekinian pada generasi milenial Surabaya.}

Berdasarkan hasil penelitian dan dikung oleh penelitian terdahulu, maka pada hasil penelitian bisa dibuat kesimpulan bahwa $\mathrm{H} 2$ diterima yaitu variabel gaya hidup hangout berpengaruh terhadap keputusan pembelian di kedai kopi kekinian pada generasi milenial Surabaya. Hasil uji t pada variabel gaya hidup hangout (X2) menunjukkan nilai signifikansi sebesar 0,000 tidak lebih dari 0,05 yang bermakna signifikan dan nilai t hitungnya lebih banyak dibandingkan $\mathrm{t}$ tabelnya $(5,749>1,987)$. Maka kesimpulan yang diambil yaitu gaya hidup hangout (X2) berpengaruh terhadap keputusan pembelian (Y), sehingga hipotesis kedua dapat diterima. Penelitian ini bertujuan mengetahui pengaruh dari gaya hidup hangout terhadap keputusan pembelian di kedai kopi kekinian pada generasi milenial Surabaya.

Gaya hidup hangout memiliki 3 indikator pengukuran yaitu aktivitas, minat dan opini. Gaya hidup hangout di kedai kopi kekinian Surabaya dapat dilihat dari 1) senang melakukan aktivitas hangout bersama teman-teman atau keluarga di kedai kopi kekinian. 2) Datang di kedai kopi kekinian untuk bersantai, menghabiskan waktu luang dan memposting aktivitas hangout di media sosial. 3) Kedai kopi kekinian memberikan ketertarikan tersendiri dari produk kedai kopi yang lain. 4) Brand kopi di kedai kopi kekinian merupakan bagian dari hidup dan meningkatkan popularitas.

Gaya hidup hangout pada masa pandemi covid memiliki perbedaan sangat besar yaitu kegiatan nongkrong menjadi perhatian khusus yang harus dihindari, padahal kegiatan berkumpul merupakan budaya di Indonesia. Budaya nongkrong di kedai-kedai kopi kekinia pada masa pandemic covid tetap menjadi tren, dimana kegiatan berkumpul boleh dilaksanakan tetapi harus mematuhi berbagai persyaratan yang dikeluarkan oleh pemerintah seperti mematuhi protocol kesehatan, memakai masker, jumlah pengunjung dibatasi.
Dari hasil penyebaran angket melalui googlefrom bahwa variabel gaya hidup hangout pada pernyataan senang melakukan aktivitas hangout bersama temanteman atau keluarga di kedai kopi kekinian dan memposting aktivitas hangout di media sosial mendapatkan presentase tertinggi yaitu 30,5\%. Artinya berdasarkan data yang diperoleh melalui pengumpulan data googleform pada responden di Surabaya bahwa gaya hidup hangout pada pembelian di kedai kopi kekinian Surabaya yaitu umumnya membeli di kedai kopi kekinian karena melakukan aktivitas hangout bersama temanteman atau keluarga dan memposting aktivitas hangout di media sosial.

Hasil ini sesuai dengan pernyataan Dwiastuti, (2012:75) gaya hidup mengacu pada cara pakai yang menggambarkan pilihan seseorang dari penghabisan uang dan waktu. Hal ini menyatakan bahwa gaya hidup sebagai faktor yang beregaruh terhadap perilaku konsumen dalam pembelian. Hasil penelitian ini juga diperkuat oleh Pangestuti (2018) yang menunjukkan bahwa variabel gaya hidup memiliki pengaruh yang signifikan terhadap variabel keputusan pembelian. Sepemikiran dengan penelitian yang dilakukan oleh Deliana (2018) bahwa gaya hidup berhubungan kuat menuju sangat kuat dengan keputusan pembelian konsumen serta memiliki pengaruh yang positif dan searah. Yusuf, dkk (2019) mengemukakan bahwa gaya hidup berpengaruh signifikan terhadap konsumsi minuman ringan karena keselarasan kepribadian, konsep diri, dan gaya hidup menghasilkan pengaruh yang positif dan berpengaruh signifikan terhadap konsumsi minuman ringan. Penelitian ini juga didukung penelitian Astawa, dkk (2020) yang mengemukakan bahwa Perilaku konsumtif yang menjadi ciri khas generasi $\mathrm{Z}$ ini berbeda dengan generasi sebelumnya generasi, hal ini karena mereka selalu mencari informasi terkini, informasi yang digunakan dalam memutuskan membeli produknya

Berdasarkan hasil penelitian yang juga didukung oleh penelitian sebelumnya, jadi diketahui bahwa $\mathrm{H} 2$ diterima yaitu gaya hidup hangout berpengaruh terhadap keputusan pembelian di kedai kopi kekinian Surabaya.

\section{Pengaruh Self-Actualization $\left(\mathrm{X}_{1}\right)$ dan gaya hidup hangout $\left(\mathrm{X}_{2}\right)$ terhadap keputusan pembelian $(\mathrm{Y}) \mathrm{di}$ kedai kopi kekinian pada generasi milenial Surabaya.}

Berdasarkan Kotler \& Amstrong (2014), keputusan pembelian ialah langkah pengambilan keputusan pembeli yang benar-benar membeli. Di kedai kopi kekinian konsumen melakukan keputusan pembelian karena Self-Actualization dan gaya hidup hangout. Sedangkan Prasetijo dan Ihalauw (2005:226) 
keputusan menjadi suatu pilihan tindakan dari lebih dari 2 alternatif. Hal ini membuktikan gaya hidup menjadi faktor yang mempengaruhi perilaku pembeli.

Salendra (2014) membuktikan bahwa aktualisasi diri berpengaruh positif terhadap keputusan pembelian. Yusuf, dkk (2019). Gaya hidup berpengaruh signifikan terhadap konsumsi minuman ringan. Kepribadian, konsep diri, dan gaya hidup secara bersamaan mempengaruhi konsumsi minuman ringan.

Berdasarkan hasil penelitian tersebut dan penelitian pendukung lainnya, jadi pada penelitian ini dapat diketahui bahwa H3 diterima yaitu Self-Actualization dan gaya hidup hangout berpengaruh terhadap keputusan pembelian di kedai kopi kekinian Surabaya.

\section{KESIMPULAN DAN SARAN}

Kesimpulan dari pembahasan diatas, dihasilkan analisis data mengenai pengaruh Self-Actualization dan gaya hidup hangout terhadap keputusan pembelian di kedai kopi kekinian pada generasi milenial Surabaya, yatu Self-Actualization berpengaruh signifikan terhadap keputusan pembelian di kedai kopi kekinian pada generasi milenial Surabaya. Gaya hidup hangout berpengaruh signifikan terhadap keputusan pembelian di kedai kopi kekinian pada generasi milenial Surabaya.Self-Actualization dan gaya hidup hangout berpengaruh secara simultan terhadap keputusan pembelian di kedai kopi kekinian pada generasi milenial Surabaya

\section{DAFTAR PUSTAKA}

Anoraga, B. J., \& Iriani, S. S. (2018). Pengaruh gaya hidup dan kelompok acuan terhadap keputusan pembelian smartphone merek Samsung Galaxy. BISMA (Bisnis dan Manajemen), 6(2), 139-147.

Cahya. Kahfi. 2017. "Budaya Nongkrong di Kedai Kopi yang Tak Pernah Pudar". Kompas.com. diakses pada 15 Januari 2019 melalui web https://lifestyle.kompas.com/read/2017/11/10/08 1400420/budaya-nongkrong-di-kedai-kopiyang-tak-pernah-pudar.

Feist, J. \& Gregory J. Feist. (2017). Teori Kepribadian (Edisi kedelapan). Jakarta: Penerbit Salemba Humanika.

Fitrayanti, V. (2015). The Influence of Personal And Psychological Factors Toward Consumer Purchase Decision (Case Study: Petersaysdenim, Bandung) (Doctoral dissertation, President University).

Januari 2019 melalui web https://surabaya.bisnis.com/ $\mathrm{read} / 20191001 / 531 / 115444 /$ pertumbuhan-kafeberbasis-kopi-jatim-mencapai-18persen-setahun .
Kedai Kopi, Bisnis masa kini, Menjanjikan di masa depan, 25Oktober 2019. https://www.suara.com/ yoursay/2019/10/25/065000/kdai-kopi-bisnismasa-kini-menjanjikan-di-masa-depan.

Kotler, Philip dan Armstrong, Gary. 2012. Prinsipprinsip Pemasaran. Jakarta: Erlangga.

Maholtra, Naresh K. 2010. Riset Pemasaran. Jakarta: PT Indeks.

Mowen, Jhon C. dan Michael Minor. 2002. Perilaku Konsumen. Jilid Kedua. Alih Bahasa: Dwi Kartini. Jakarta: Erlangga.

Mangkunegara, A.P. 2009. Perilaku Konsumen. Edisi Revisi. Cetakan Keempat. Bandung: PT Refika Aditama, 4.

Menjadi Generasi milenial yang selalu kreatif, aktif, dan inovatif, 13 Januari 2018. https://www.kompasiana.com/belfast/5a598c1dbde575d8c498382 /menjadi generasi-millennial-yang-selalu kreatifaktif-dan-inovatif.

Prasitejo dan lhalauw. (2005). Perilaku konsumen. Edisi ke 1. Yogyakarta: Andi Offset.

Salendra, S. (2014). Coffee Shop As a Media for SelfActualization Today's Youth. Jurnal The Messenger, 6(2), 49-57.

Soewartini, S., Sumarwan, U., Sukandar, D., \& Yusuf, E. Z. The Relationship Model of Personality, Self-Concept, and Lifestyle on Soft Drink Consumption

Schiffman, L.G dan Kanuk. 2004. Perilaku Konsumen. Hal 289. Jakarta: Ghalia Indonesia.

Subawa, N. S., Widhiasthini, N. W., Pika, P. A. T. P., Suryawati, P. I., \& Astawa, I. N. D. (2020). Generation Z Behavior And Low Price Products In The Era Of Disruption. International Journal of Social Sciences and Management Review, 3(3), 1-12.

Sholeh, A. (2017). The relationship among hedonistic lifestyle, life satisfaction, and happiness on college students. International Journal of Social Science and Humanity, 7(9), 604-607.

Ujang Sumarwan. 2011. Perilaku Konsumen Teori dan Peneraanya dalam Pemasaran. 11-12. Jakarta: Ghalia Indonesia.

Widarti, peni. 2019. Pertumbuhan kafe berbasis kopi jatim mencapai 18 persen setahun. Suara bisnis.com. diakses tanggal 16.

Wijaya, D. N., Sunarti, S., \& Pangestuti, E. (2018). Pengaruh Gaya Hidup Dan Motivasi Terhadap Keputusan Pembelian (Survei Pada Konsumen Starbucks, Kota Malang). Jurnal Administrasi Bisnis, 55(2), 68-74.

Yulianti, Y., \& Deliana, Y. (2018). Gaya Hidup kaitannya dengan keputusan konsumen dalam membeli minuman kopi. Jurnal Agrisep, 17(1), 39-50. 